\title{
A Robust Open Framework Formed by Decavanadate Clusters and Copper(II) Complexes of Macrocyclic Polyamines: Permanent Mi- croporosity and Catalytic Oxidation of Cycloalkanes
}

\author{
Jagoba Martín-Caballero, ${ }^{\dagger}$ Ana San José Wéry, ${ }^{\ddagger}$ Santiago Reinoso, ${ }^{\S}$ Beñat Artetxe, ${ }^{\dagger}$ Leire San Feli- \\ ces, $\|$ Bouchra El Bakkali, ${ }^{\perp}$ Guido Trautwein, ${ }^{\perp}$ Juan Alcañiz-Monge, ${ }^{\perp}$ José Luis Vilas ${ }^{*}+, \#$ and Juan \\ M. Gutiérrez-Zorrilla*,†,§ \\ †BCMaterials, Parque Tecnológico de Bizkaia, Edificio 50o, 4816o Derio, Spain. \\ ‡Departamento de Desarrollo Sostenible, Universidad Católica de Ávila, c/Canteros s/n, o5005 Ávila, Spain. \\ §Departamento de Química Inorgánica, Facultad de Ciencia y Tecnología, Universidad del País Vasco UPV/EHU, P.O. Box 644, \\ 4808o Bilbao, Spain.
}

"Servicios Generales de Investigación SGIker, Facultad de Ciencia y Tecnología, Universidad del País Vasco UPV/EHU, P.O. Box 644, 48o8o Bilbao, Spain.

${ }^{\perp}$ Grupo de Materiales Carbonosos y Medio Ambiente, Departamento de Química Inorgánica, Facultad de Ciencias, Universidad de Alicante, P.O. Box 99, o3o8o Alicante, Spain.

\#Departamento de Química Física, Facultad de Ciencia y Tecnología, Universidad del País Vasco UPV/EHU, P.O. Box 644, 4808o Bilbao, Spain.

\begin{abstract}
The first decavanadate-based microporous hybrid, namely, $[\mathrm{Cu}($ cyclam $)]\left[\{\mathrm{Cu}(\mathrm{cyclam})\}_{2}\left(\mathrm{~V}_{10} \mathrm{O}_{28}\right)\right] \cdot 10 \mathrm{H}_{2} \mathrm{O}(\mathbf{1}$, cyclam $=1,4,8,11$-tetraazacyclotetradecane) has been prepared by reaction of $\left(\mathrm{VO}_{3}\right)^{-}$anions and $\{\mathrm{Cu}(\mathrm{cyclam})\}^{2+}$ complexes in $\mathrm{NaCl}(\mathrm{aq})$ at $\mathrm{pH}$ 4.6-4.7, and characterized by elemental analyses, thermogravimetry, and X-ray diffraction techniques (powder, single-crystal). Compound 1 exhibits a POMOF-like supramolecular open-framework built up of covalent decavanadate/metalorganic layers with square-like voids, the stacking of which is aided by interlamellar cementing complexes and generates water-filled channels with approximate cross-sections of. $10.4 \times 8.8 \AA^{2}$. The framework is robust enough to remain virtually unaltered upon thermal evacuation of all water molecules of hydration, as demonstrated through single-crystal X-ray diffraction studies on the anhydrous phase 1a. This permanent microporosity renders interesting functionality to 1 , such as selective adsorption of $\mathrm{CO}_{2}$ over $\mathrm{N}_{2}$ and remarkable activity as heterogeneous catalyst toward the $\mathrm{H}_{2} \mathrm{O}_{2}$-based oxidation of the highly-stable, tricyclic alkane adamantane.
\end{abstract}

\section{INTRODUCTION}

Porous crystalline materials such as metal organic frameworks (MOFs) have attracted great attention due to their wide range of relevant applications. ${ }^{1}$ These materials are constructed by coordination of metal ions or metalcontaining units (nodes) to organic bridging ligands (linkers) to form open crystalline frameworks with permanent porosity. This feature qualifies them as suitable candidates for gas storage and separation, ion exchange, host-guest chemistry, magnetism, biomedicine and catalysis. ${ }^{2}$ However, the synthesis of MOFs usually requires harsh conditions (e.g. high temperature or pressure, prolonged reaction times, harmful solvents, etc.), and removal of guest molecules from their cavities often leads to the collapse of the porous structure when flexible linkers are used. In this context, the incorporation of rigid and voluminous species such as metal clusters could increase the overall robustness of the framework. Among metal clusters, polyoxometalates (POMs) have been identified as excellent building blocks for the construction of such robust, high-dimensional open structures. ${ }^{3}$

Polyoxometalates (POMs) are a family of anionic metal oxo clusters with large topological diversity and intrinsic multifunctional nature. ${ }^{4}$ Nowadays, POM-based crystalline solids with permanent porosity are of great interest because inherent features of POMs such as reversible redox properties or high catalytic site density can be combined with the characteristics derived from open-framework structures.35 Several examples have been reported in recent years and they include both supramolecular ionic compounds and covalent extended lattices (POMOFs). The former can be exemplified by Mizuno's series of hybrid salts in which $\left[\mathrm{M}_{3} \mathrm{O}\left\{\mathrm{RCO}_{2}\right\}_{6} \mathrm{~L}_{3}\right]^{+}$macrocations $\left(\mathrm{M}^{\mathrm{III}}=\mathrm{Cr}\right.$, Fe; $\mathrm{L}=$ terminal ligand) are combined with Keggin-type 
$\left[\mathrm{XM}_{12} \mathrm{O}_{40}\right]^{\mathrm{n}-}(\mathrm{X}=\mathrm{B}, \mathrm{Si}, \mathrm{P} ; \mathrm{M}=\mathrm{W})$ heteropolyanions in microporous structures with tunable shape-selective sorption ability. ${ }^{5}$ Among POMOFs, four different approaches for assembling clusters into extended lattices can be identified according to Wang et al.: ${ }^{6}$ ) organically derivatized POM units linked by metal ions; 7 b) POM clusters directly connected by metal ion linkers in fully inorganic openframeworks; ${ }^{8}$ c) metal-substituted POMs connected through organic bridging ligands; ${ }^{9}$ d) POMs connected through metal-organic ligand-metal linking fragments. ${ }^{10}$ Compared to MOFs, the synthetic requirements for the assembly of POMOFs usually involve milder conditions, aqueous reaction media and easier counterion exchange. Moreover, configurable and more diverse architectures can be achieved in the resulting compounds because POM building blocks possess specific topological and chemical information that can be transferred to the final product.

A fifth subclass closely related to type b) above could also be proposed: that in which the metal ion linkers belong to discrete coordination complexes with peripheral organic ligands. ${ }^{3,1}$ Even though a considerable number of covalent extended networks based on POM clusters connected through metalorganic moieties have been prepared so far, to the best of our knowledge none of such hybrid compounds have exhibited genuine functions associated with porosity (e.g. adsorption, separation). This fact might be mainly due to the presence of pores with small sizes and/or inaccessible voids. Thus, the preparation of such type of functional porous open-frameworks is still a challenging issue in current synthetic POM chemistry.

Polyoxovanadates constitute an important POM subfamily, in which $\left[\mathrm{H}_{\mathrm{n}} \mathrm{V}_{10} \mathrm{O}_{28}\right]^{(6-\mathrm{n})-}$ decavanadates are considered amongst the most relevant members as they are the predominant species in acidic aqueous solution. ${ }^{12}$ While the coordinative role of small polyoxovanadate clusters (e.g. $\left[\mathrm{V}_{4} \mathrm{O}_{12}\right]^{4-}$ ) toward transition-metal complexes has been long documented, ${ }^{13}$ most of the decavanadatemetalorganic hybrids known at present consists in ionic compounds, ${ }^{14}$ in which the structural stability simply relies on electrostatic forces and weak intermolecular interactions between the different components. Indeed, the first crystal structure involving metalorganic complex moieties covalently grafted at the surface of decavanadate anions was not reported until 2007, 15 and almost all compounds with such characteristics that have been prepared later on consist in either discrete decorated clusters ${ }^{16}$ or mono-dimensional arrangements. ${ }^{17}$ To our knowledge, only two decavanadate/metalorganic hybrid lattices with covalent bi-dimensional nature can be found in the literature, ${ }^{18}$ namely $(\mathrm{Hpz})_{2}\left[\left\{\mathrm{Cu}(\mathrm{pz})_{4}\right\}_{2}\left(\mathrm{~V}_{10} \mathrm{O}_{28}\right)\right] \cdot 2 \mathrm{H}_{2} \mathrm{O}(\mathrm{pz}=$ pyrazole $)$ and $\left[\left\{\mathrm{Ag}_{3}(\mathrm{dmso})_{6}\right\}\left\{\left(\mathrm{Ag}(\mathrm{dmso})_{2}\right\}\left(\mathrm{H}_{2} \mathrm{~V}_{10} \mathrm{O}_{28}\right)\right] \cdot 2 \mathrm{dmso}\right.$. It must be noted that none of these two compounds show porosity because of an alternate stacking of sheets that renders the cation/solvent-filled voids inaccessible.

Herein, we report the first supramolecular POMOF-like compound assembled from the stacking of covalent layers formed by decavanadate anions and metalorganic linkers, namely $[\mathrm{Cu}($ cyclam $)]\left[\{\mathrm{Cu}(\text { cyclam })\}_{2}\left(\mathrm{~V}_{10} \mathrm{O}_{28}\right)\right] \cdot 1 \mathrm{oH}_{2} \mathrm{O}$ (cyclam $=1,4,8,11$-tetraazacyclotetradecane). The robustness of the open-framework and associated permanent microporosity of $\mathbf{I}$ has been confirmed by single-crystal X-ray diffraction studies on the thermally generated anhydrous phase 1a, as well as by gas sorption measurements that reveal selective adsorption of $\mathrm{CO}_{2}$ over $\mathrm{N}_{2}$. The catalytic activity toward the $\mathrm{C}-\mathrm{H}$ bond activation of highly-stable tricyclic alkanes, such as adamantane, has been assessed in heterogeneous phase.

\section{EXPERIMENTAL SECTION}

The tert-butylammonium metavanadate $\left[\left(\mathrm{CH}_{3}\right)_{3} \mathrm{CNH}_{3}\right]\left[\mathrm{VO}_{3}\right]$ and dihydrogendecavanadate $\left[\left(\mathrm{CH}_{3}\right)_{3} \mathrm{CNH}_{3}\right]_{4}\left[\mathrm{H}_{2} \mathrm{~V}_{10} \mathrm{O}_{28}\right] \cdot 8 \mathrm{H}_{2} \mathrm{O}$ precursors were synthesized according to literature methods and identified by infrared (FT-IR) spectroscopy. ${ }^{19}$ All other chemicals were obtained from commercial sources and used without further purification. Carbon, hydrogen and nitrogen were determined on a Perkin-Elmer 2400 CHN analyzer. FT-IR spectra were obtained as $\mathrm{KBr}$ pellets on a SHIMADZU FTIR$8400 \mathrm{~S}$ spectrometer. The thermogravimetric (TGA) analysis was carried out from room temperature to $800{ }^{\circ} \mathrm{C}$ at a rate of $5^{\circ} \mathrm{C}$ min $^{-1}$ on a Mettler Toledo TGA/SDTA $85^{\mathrm{e}}$ thermobalance under a $50 \mathrm{~cm}^{3} \mathrm{~min}^{-1}$ flow of synthetic air. Powder X-ray diffraction (PXRD) patterns were collected on a Bruker D8 Advance diffractometer operating at $30 \mathrm{kV} / 20$ $\mathrm{mA}$ and equipped with $\mathrm{Cu} \mathrm{K}_{\alpha}$ radiation $(\lambda=1.5418 \AA)$, a Vantec-1 PSD detector, an Anton Parr HTK20oo high-temperature furnace, and Pt sample holder. The powder patterns were recorded in $2 \theta$ steps of $0.033^{\circ}$ in the $5 \leq 2 \theta \leq 35$ range with an exposure time of $0.3 \mathrm{~s}$ per step. Data sets were acquired from 30 to $490^{\circ} \mathrm{C}$ every $20^{\circ} \mathrm{C}$, with a heating rate of a $0.16^{\circ} \mathrm{C} \mathrm{s}^{-1}$ between temperatures.

\section{Synthetic Procedure}

$[\mathrm{Cu}($ cyclam $)]\left[\{\mathrm{Cu}(\text { cyclam })\}_{2}\left(\mathrm{~V}_{10} \mathrm{O}_{28}\right)\right] \cdot 1 \mathrm{oH}_{2} \mathrm{O}$ $\left[\left(\mathrm{CH}_{3}\right)_{3} \mathrm{CNH}_{3}\right]\left[\mathrm{VO}_{3}\right]$ (o.170 g, $1.00 \mathrm{mmol}$ ) was dissolved in aqueous $1 \mathrm{M} \mathrm{NaCl}(20 \mathrm{~mL})$ and the $\mathrm{pH}$ was adjusted to $4.6-$ 4.7 with aqueous $0.5 \mathrm{M} \mathrm{HCl}$. Then, a solution of $\mathrm{CuSO}_{4} \cdot{ }_{5} \mathrm{H}_{2} \mathrm{O}$ (0.075 g, $0.30 \mathrm{mmol}$ ) and cyclam (0.040 g, $0.20 \mathrm{mmol})$ in aqueous $1 \mathrm{M} \mathrm{NaCl}(15 \mathrm{~mL})$ was added dropwise. The mixture was stirred for $\mathbf{2}$ hours and then filtered to remove a brown solid off. The resulting dark brown solution was left to slowly evaporate in an open container at room temperature and orange block-like crystals suitable for X-ray diffraction were obtained after 6 days. Yield: 44 $\mathrm{mg}$ (23\% based on $\mathrm{V}$ (atomic). Anal. Calcd (found) for $\mathrm{C}_{30} \mathrm{H}_{92} \mathrm{Cu}_{3} \mathrm{~N}_{12} \mathrm{O}_{38} \mathrm{~V}_{10}$ : C, 18.68 (18.51); H, 4.80 (4.69); N, 8.71 (8.60). IR $\left(\mathrm{cm}^{-1}\right)$ : 3186(vs), 3165(vs), 2934(s), 2878(s), $1627(\mathrm{~s}), \quad 1473(\mathrm{~m}), \quad 1454(\mathrm{~m}), \quad 1427(\mathrm{~m}), \quad 1389(\mathrm{w}), \quad 1358(\mathrm{w})$, $1300(\mathrm{w}), 1253(\mathrm{w}), 1236(\mathrm{w}), 1138(\mathrm{~m}), 1105(\mathrm{~m}), 1062(\mathrm{~m})$, $1009(\mathrm{~m}), 960(\mathrm{vs}), 883(\mathrm{~m}), 835(\mathrm{~s}), 748(\mathrm{~s}), 594(\mathrm{~s}), 532(\mathrm{~s})$, 559(s), 440(s).

$[\mathbf{C u}($ cyclam $)]\left[\{\mathbf{C u}(\text { cyclam })\}_{2}\left(\mathbf{V}_{10} \mathbf{O}_{28}\right)\right] \cdot(\mathbf{1 a})$. The anhydrous derivative 1 a can be obtained by heating single-crystals of 1 at $130{ }^{\circ} \mathrm{C}$ in an oven for 1 h. A color change from orange to amber was produced upon dehydration. 


\section{X-ray Crystallography}

Crystallographic data for compounds $\mathbf{1}$ and $\mathbf{1 a}$ are given in Table 1. Intensity data were collected on an Agilent Technologies Super-Nova diffractometer. The diffractometer was equipped with monochromated $\mathrm{Cu} \mathrm{K}_{\alpha}$ radiation $(\lambda$ $=1.54184 \AA$ ) and Atlas CCD detector in the case of $\mathbf{1}$, whereas the selected radiation and detector for 1a were monochromated Mo $K_{\alpha}(\lambda=0.71073 \AA)$ and Eos CCD. The data collection of $\mathbf{1}$ was carried out at $100 \mathrm{~K}$. In the case of 1a, a single crystal of $\mathbf{1}$ was heated in an oven to $303 \mathrm{~K}$ at a rate of $1 \mathrm{~K} \mathrm{~min}^{-1}$ to achieve full dehydration, and immediately afterwards covered with Paratone ${ }^{\circledast}$ oil and placed under the $\mathrm{N}_{2}$ stream of the diffractometer, which was ready to perform a full data collection at $100 \mathrm{~K}$. Data frames were processed (unit cell determination, analytical absorption correction with face indexing, intensity data integration and correction for Lorentz and polarization effects) using the CrysAlis Pro software package. ${ }^{20}$ The structures were solved using OLEX2 ${ }^{21}$ and refined by full-matrix leastsquares with SHELXL-2014/6. ${ }^{22}$ Final geometrical calculations were carried out with PLATON ${ }^{23}$ as integrated in WinGX. ${ }^{24}$ Thermal vibrations were treated anisotropically for all non-H atoms in both compounds. Hydrogen atoms of the organic ligands were placed in calculated positions and refined using a riding model with standard SHELXL parameters. Ten positions suitable for water molecules of hydration were located in the Fourier map of $\mathbf{1}$ and their occupancy was initially refined without restrictions. The resulting total number of 5.5 water molecules per half of decavanadate cluster was fixed to 5 during the final refinement as indicated by the TGA experiments. The space within the channels occupied by the water molecules of hydration was visualized by PyMol. ${ }^{25}$

\section{Sorption Measurements}

The porous texture of $\mathbf{1}$ was characterized through the physical adsorption of the following gases: $\mathrm{N}_{2}$ at $-196{ }^{\circ} \mathrm{C}$ and $\mathrm{CO}_{2}$ at ${ }^{\circ}{ }^{\circ} \mathrm{C}$. The volumetric equipments Autosorb-6B and Autosorb-6 were used respectively. The measurements were performed on crystalline samples that were previously outgassed at $150{ }^{\circ} \mathrm{C}$ under vacuum for 4 hours. The Dubinin-Radushkevich (DR) equation ${ }^{26 a}$ was used to calculate the micropore volume. The calculation of pore volumes has been done as follows: $a)$ the volume of the narrow micropores or ultramicropores $\left(\mathrm{V}_{\mathrm{CO}_{2}}\right.$, pore size $<0.8$ $n m$ ) was estimated from the $\mathrm{CO}_{2}$ DR plots at relative $\mathrm{P} / \mathrm{P}_{0}$ pressures lower than 0.015 ; b) the total volume of micropores $\left(\mathrm{V}_{\mathrm{N}_{2}}\right.$, pore size $\left.<2 \mathrm{~nm}\right)$ was calculated from $\mathrm{N}_{2}$ DRs plots at relative $\mathrm{P} / \mathrm{P}_{\mathrm{o}}$ pressures lower than $0.14 .{ }^{26 \mathrm{~b}}$

\section{Catalytic tests}

The oxidation of adamantane was conducted in a glass reactor ( $27 \mathrm{~cm}^{3}$ of inner volume) located inside a stainless steel vessel ( $45 \mathrm{~cm}^{3}$ of inner volume) coupled to a manometer to monitor the system pressure. The following reactants and solvent were used for the catalytic test: $25 \mathrm{mg}$ of adamantane, $3 \mathrm{~cm}^{3}$ of hydrogen peroxide (30\%), $10 \mathrm{~cm}^{3}$ of acetonitrile, two drops of concentrated $\mathrm{HCl}$ and $100 \mathrm{mg}$ of the catalyst $1\left(5 \cdot 10^{-5}\right.$ moles $)$. For comparative purposes,
$\mathrm{V}_{2} \mathrm{O}_{5}$ (Aldrich), and two Keggin-type heteropolyacids supported on $\mathrm{ZrO}_{2}\left(\mathrm{H}_{3}\left[\mathrm{PMo}_{12} \mathrm{O}_{40}\right]\right.$ and $\mathrm{H}_{4}\left[\mathrm{PVMo}_{11} \mathrm{O}_{40}\right]$, 30 wt.\% of POM) were also tested. A small Teflon-coated magnet was added to the mixture and the whole system was immersed in a thermostatic bath of polyethylene glycol at 75 ${ }^{\circ} \mathrm{C}$ while stirring at $800 \mathrm{rpm}$. A reaction time of 6 hours was selected as the optimum value to allow for complete conversion but minimizing hydrogen peroxide decomposition. Both shorter ( 3 hours) and longer (up to 12 hours) reaction times were also tested for comparative purposes. The reaction products of the oxidation of adamantane were identified by analyzing an aliquot of the solution $(20 \mu \mathrm{L})$ taken at the end of the reaction time with an Agilent 6890 gas chromatograph equipped with an HP-1 column of size 30 $\mathrm{m} \times 250 \mu \mathrm{m} \times 0.25 \mu \mathrm{m}$ and coupled to an Agilent 5975 mass spectrometer. Upon identification of all reaction products, the conversion and their evolution were quantitatively estimated using a flame ionization detector coupled to a properly calibrated Agilent 6890 gas chromatograph.

\section{Table 1. Crystallographic data for 1 and $1 a$}

\begin{tabular}{|c|c|c|}
\hline & $\mathbf{1}$ & la \\
\hline \multirow[t]{2}{*}{ Empirical formula } & $\mathrm{C}_{30} \mathrm{H}_{92} \mathrm{Cu}_{3}$ & $\mathrm{C}_{30} \mathrm{H}_{72} \mathrm{Cu}_{3}$ \\
\hline & $\mathrm{N}_{12} \mathrm{O}_{38} \mathrm{~V}_{10}$ & $\mathrm{~N}_{12} \mathrm{O}_{28} \mathrm{~V}_{10}$ \\
\hline $\mathrm{FW}\left(\mathrm{g} \mathrm{mol}^{-1}\right)$ & 1929.2 & 1749.0 \\
\hline Crystal system & triclinic & triclinic \\
\hline Space group & $\mathrm{P}-1$ & $\mathrm{P}-1$ \\
\hline Temperature (K) & $100(2)$ & $100(2)$ \\
\hline$a(\AA)$ & $10.6665(8)$ & $10.6838(3)$ \\
\hline$b(\AA)$ & $11.9325(9)$ & $11.9275(6)$ \\
\hline$c(\AA)$ & $13.7832(8)$ & $13.7285(7)$ \\
\hline$\alpha\left(^{\circ}\right)$ & $95 \cdot 75^{2}(5)$ & $94 \cdot 433(4)$ \\
\hline$\beta\left(^{\circ}\right)$ & $105.003(6)$ & $104 \cdot 596(3)$ \\
\hline$\gamma\left({ }^{\circ}\right)$ & $90.677(6)$ & $92.604(3)$ \\
\hline$V\left(\AA^{3}\right)$ & $1684.7(2)$ & $1684.08(13)$ \\
\hline$\rho_{\text {calc }}\left(\mathrm{g} \mathrm{cm}^{-3}\right)$ & 1.902 & 1.725 \\
\hline$\mu\left(\mathrm{mm}^{-1}\right)$ & 12.928 & 2.320 \\
\hline$\lambda(\AA)$ & $1.54184(\mathrm{Cu} \mathrm{K})$ & $0.71073\left(\right.$ Mo K $\left._{\alpha}\right)$ \\
\hline collected reflns & 11577 & 10744 \\
\hline unique reflns $\left(\mathrm{R}_{\text {int }}\right)$ & $5977(0.046)$ & 5939 (o.027) \\
\hline obsd reflns $[\mathrm{I}>2 \sigma(\mathrm{I})]$ & 4821 & 4595 \\
\hline parameters & 469 & 379 \\
\hline$R(F)^{\mathrm{a}}[\mathrm{I}>2 \sigma(\mathrm{I})]$ & 0.057 & 0.040 \\
\hline$w R\left(F^{2}\right)^{\mathrm{b}}$ [all data] & 0.166 & 0.102 \\
\hline GoF & 1.038 & 1.044 \\
\hline
\end{tabular}




\section{RESULTS AND DISCUSSION}

\section{Synthesis}

Recently, we reported a new porous metavanadate$\{\mathrm{Cu}($ cyclam $)\}$ hybrid able to undergo as much as three sequential and reversible SCSC transformations promoted by gradual dehydration upon heating from room temperature to $120{ }^{\circ} \mathrm{C}^{27}$ This compound was prepared from the self-assembly of $\left\{\mathrm{VO}_{3}\right\}^{-}$anions and $\{\mathrm{Cu}(\text { cyclam })\}^{2+}$ complexes in basic aqueous medium under reflux conditions with the optimum $\mathrm{pH}$ value set at 9 . Our systematic investigation of the influence of $\mathrm{pH}$ on the $\mathrm{VO}_{3}^{-}: \mathrm{Cu}^{2+}$ : cyclam synthetic system allowed us to determine that such metavanadate hybrid could only be obtained at $\mathrm{pH}$ values above 6 . We also found that a second decavanadate-containing hybrid derivative crystallized in the $\mathrm{pH}$ range $4^{-6}$, but unfortunately, this compound could only be isolated as traces in a mixture with an unidentified powder. Given the interesting thermal-dependent crystallochemistry observed in our previous work, we decided to optimize the synthetic procedure for this decavanadate-containing hybrid (1) and to investigate whether this compound could exhibit similar temperature-dependent crystal transitions as well.

We limited our synthetic studies to the $\mathrm{pH}$ range 4-6 and conducted several experiments in aqueous media to check the influence of the following parameters on the reaction outcome: $\mathrm{pH}$, temperature, type of precursor (metavanadate vs. decavanadate), and solvent. Neither the temperature nor the precursors appear to have any apparent effect on the final product, as reactions carried out at different temperatures up to reflux conditions or using the preformed $\left[\left(\mathrm{CH}_{3}\right)_{3} \mathrm{CNH}_{3}\right]_{4}\left[\mathrm{H}_{2} \mathrm{~V}_{10} \mathrm{O}_{28}\right] \cdot 8 \mathrm{H}_{2} \mathrm{O}$ resulted in similar mixtures of crystals of $\mathbf{1}$ with the powder as the major component. In contrast, the $\mathrm{pH}$ plays a key role for the isolation of the hybrid decavanadate in a pure manner. We managed to prepare $\mathbf{1}$ as a single, homogeneous crystalline phase at a controlled $\mathrm{pH}$ value of $4.6-4.7$ as evidenced by the FT-IR spectra and the PXRD patterns (Figures $\mathrm{S}_{1}-\mathrm{S}_{3}$ in the Supporting Information), although the yield obtained was still certainly poor (around $1 \%$ with cyclam as the limitant). This is due to the formation of large amounts of a brown precipitate as the reaction proceeds, which contains the title compound but in impure bulk form as evidenced by FT-IR and PXRD analyses (Figures $\mathrm{S}_{4}$ in the Supporting Information).

Fortunately, a change in the solvent favored the formation of our hybrid decavanadate by increasing the yield of the crystalline phase and reducing the time for crystallization. When water was replaced with aqueous $1 \mathrm{M} \mathrm{NaCl}$ and the optimized conditions determined above were applied (metavanadate precursor, room temperature, $\mathrm{pH}$ 4.6-4.7), formation of the impure bulk form was minimized and crystallization of $\mathbf{1}$ took place in a few days instead of the several weeks needed in the original attempts. The resulting yield was drastically improved to above $20 \%$, proving that the ionic strength has a key influence in this particular synthetic system. It is worth mentioning that we also tried to prepare analogues of $\mathbf{1}$ but using other divalent transition metals $\left(\mathrm{Mn}^{\mathrm{II}}, \mathrm{Co}^{\mathrm{II}}, \mathrm{Ni}^{\mathrm{II}}\right.$, and $\left.\mathrm{Zn}^{\mathrm{II}}\right)$ instead of $\mathrm{Cu}^{\mathrm{II}}$, but unfortunately, we could not obtain any crystalline material from these experiments. This fact confirms that the plasticity of the coordination sphere of the $\mathrm{Cu}^{\mathrm{II}}$ centers and the Jahn-Teller elongation they undergo when involved in octahedral environments play a key role in the formation of $\mathbf{1}$, as it will be shown in the structural description below.

\section{Thermo-structural behavior}

The thermal stability of $\mathbf{1}$ was investigated by TGA experiments, which show that the title compound decomposes through three mass loss stages (Figure 1). The first stage is observed from room temperature to $c a .95{ }^{\circ} \mathrm{C}$ and originates from the release of all water molecules of hydration. The experimental mass loss corresponds to 10 water molecules per decavanadate anion (calcd. 9.33\%, found 8.94\%). Completion of this stage leads to the anhydrous phase $\mathbf{1 a}$, which shows a significant range of thermal stability extending up to $c a$. $160{ }^{\circ} \mathrm{C}$. Above this temperature, the anhydrous phase undergoes further decomposition via two overlapping mass loss stages associated with the combustion of the organic ligands and the breakdown of the POM framework. The overall mass loss for these two stages is in good agreement with three cyclam ligands per decavanadate anion (calcd. for ${ }_{3} \mathrm{C}_{10} \mathrm{H}_{24} \mathrm{~N}_{4} 31.10 \%$; found $32.11 \%)$. The final residue is obtained at temperatures above ca. $550{ }^{\circ} \mathrm{C}$ (calcd. for $\mathrm{Cu}_{3} \mathrm{O}_{28} \mathrm{~V}_{10} 59.50 \%$, found $58.95 \%)$.

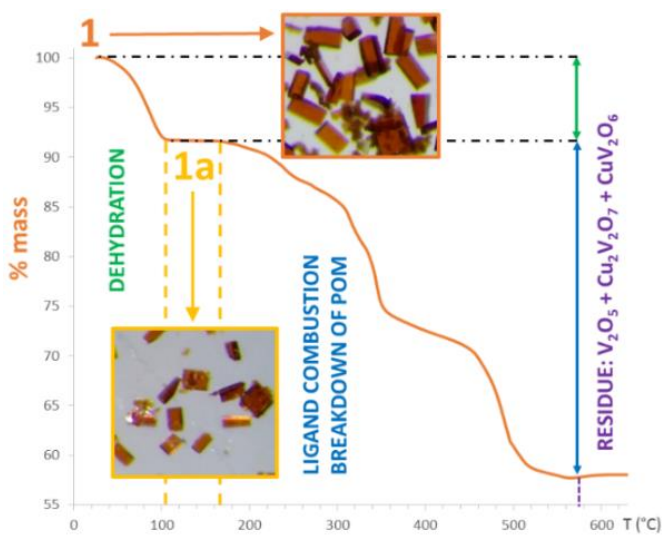

Figure 1. TGA curve of $\mathbf{1}$ and photographs of crystals for $\mathbf{1}$ and its anhydrous derivative $\mathbf{1 a}$.

Variable-temperature powder $\mathrm{X}$-ray diffraction measurements (TPXRD) between 30 and $490{ }^{\circ} \mathrm{C}$ show that compound $\mathbf{1}$ is able to maintain its crystallinity upon dehydration up to temperatures in the 150 to $170{ }^{\circ} \mathrm{C}$ range (Figure 2). No substantial modifications in neither the positions nor the intensities of the diffraction maxima are observed upon heating, although subtle variations can be noticed above $90{ }^{\circ} \mathrm{C}$ upon close inspection of the group of maxima in the $2 \theta$ range $25-27^{\circ}$. This temperature corresponds to the removal of all water molecules of hydration according

to the TGA curve, and hence to the formation of the anhydrous 1a phase, which must display virtually identical crystal packing based on the observations above. The crystalline 1a phase becomes amorphous at temperatures above $150^{\circ} \mathrm{C}$ which nearly corresponds to the beginning of 
the ligand combustion stage in the TGA curve. Signs of new high-temperature phases start appearing at $c a .310{ }^{\circ} \mathrm{C}$. At temperatures above $490^{\circ} \mathrm{C}$, these phases forming the final residue of the thermal decomposition are defined enough for being identified as a mixture of orthorhombic $\mathrm{Pmn}_{21}$ $\mathrm{V}_{2} \mathrm{O}_{5}$ (PDF: 01-076-1803), ${ }^{28}$ monoclinic $C_{2 / c} \mathrm{Cu}_{2} \mathrm{~V}_{2} \mathrm{O}_{7}$ (PDF: 01-073-1032), ${ }^{29}$ and the orthorhombic $\mathrm{Pmn}_{21}$ phase of $\mathrm{CuV}_{2} \mathrm{O}_{6}$ (PDF: oo- $\left.016-0127\right)^{30}$ in an approximate ratio 3:1 :1. (Figure $\mathrm{S}_{5}$ in the Supporting Information).

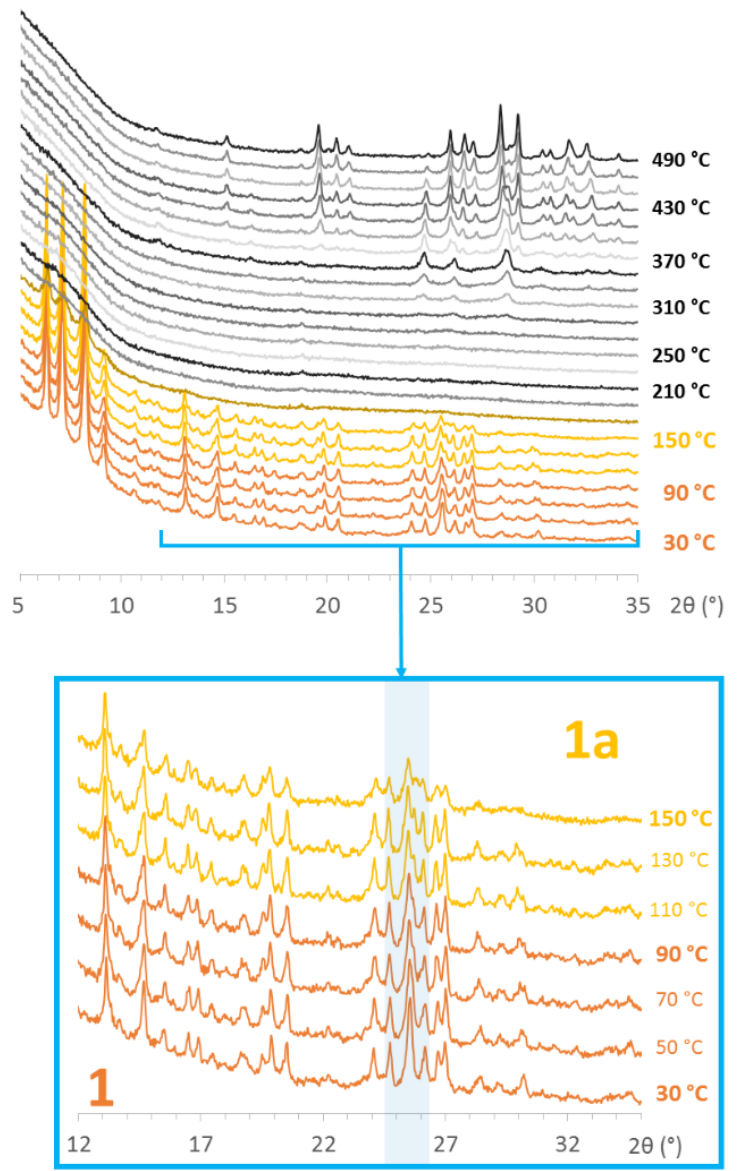

Figure 2. Variable-temperature powder X-ray diffraction studies for $\mathbf{1}$.

\section{Crystal structures of 1 and $1 \mathrm{a}$}

Compound $\mathbf{1}$ crystallizes in the triclinic $P-\mathbf{1}$ space group and its asymmetric units contains one half of a decavanadate $\left(\mathrm{V}_{10} \mathrm{O}_{28}\right)^{6-}$ anion and three crystallographically independent, centrosymmetric $\{\mathrm{Cu}(\mathrm{cyclam})\}$ moieties (Figure 2). Five water molecules of hydration disordered over ten positions complete the asymmetric unit. The structure of the decavanadate anion is well established and consists in an arrangement of 10 edge-shared $\left\{\mathrm{VO}_{6}\right\}$ octahedra with ideal $D_{2 h}$ symmetry. This arrangement can be described as a central $\left\{\mathrm{V}_{6} \mathrm{O}_{12}\right\}$ core built of six $\mathrm{VO}_{6}$ octahedra arranged in a $2 \times 3$ rectangular array and capped with two additional $\left\{\mathrm{VO}_{6}\right\}$ units on both sides (Figure 3 and $\mathrm{S} 6$ in the Supporting Information). The V-O bond lengths (Table $\mathrm{S} 1$ in the Supporting Information) are consistent with other decavanadate clusters reported in the literature. ${ }^{19 b, 31}$

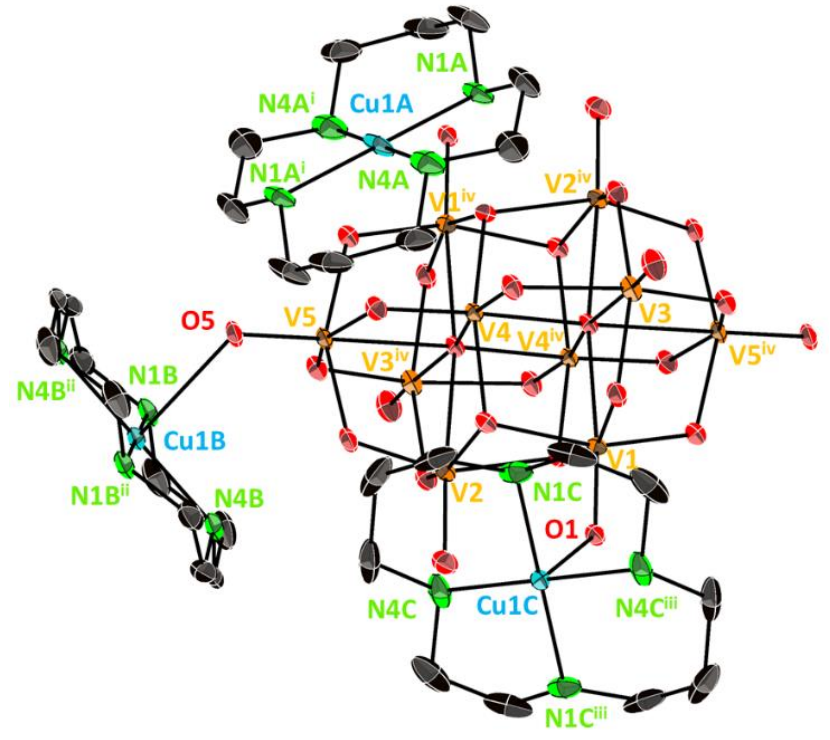

Figure 3. ORTEP view of 1 depicted at the $50 \%$ probability level, together with atom labelling (water molecules are omitted for clarity). Symmetry codes: i) $1-x, 1-y,-z$; ii) $2-x, 1-y, 1-$ $z$; iii) $2-x,-y,-z$; iv) $2-x, 1-y,-z$.

Table 2. Bond lengths ( $\AA$ ) of the Copper(II) Centers in 1 and $1 \mathrm{a}$

\begin{tabular}{|c|c|c|c|}
\hline \multicolumn{2}{|c|}{1} & \multicolumn{2}{|c|}{$1 a$} \\
\hline $\mathrm{Cu} A \mathrm{~A}-\mathrm{N}_{1} \mathrm{~A}$ & $1.995(5)$ & $\mathrm{Cu} A \mathrm{~A}-\mathrm{N} 1 \mathrm{~A}$ & $1.999(4)$ \\
\hline $\mathrm{Cu} A-\mathrm{Nl}^{\mathrm{i}}$ & $1.995(5)$ & $\mathrm{Cu} A \mathrm{~A}-\mathrm{N}_{1} \mathrm{~A}^{\mathrm{i}}$ & $1.999(4)$ \\
\hline $\mathrm{Cu}_{1} \mathrm{~A}-\mathrm{N}_{4} \mathrm{~A}$ & $1.992(7)$ & $\mathrm{Cu} A \mathrm{~A}-\mathrm{N}_{4} \mathrm{~A}$ & $1.997(4)$ \\
\hline $\mathrm{Cu} A-\mathrm{N}_{4} \mathrm{~A}^{\mathrm{i}}$ & $1.992(7)$ & $\mathrm{Cu} A-\mathrm{N}_{4} \mathrm{~A}^{\mathrm{i}}$ & $1.997(4)$ \\
\hline $\mathrm{Cu} B-\mathrm{N}_{1} \mathrm{~B}$ & $2.001(5)$ & $\mathrm{Cu} B-\mathrm{N} 1 \mathrm{~B}$ & $2.003(4)$ \\
\hline $\mathrm{Cu} B \mathrm{~B}-\mathrm{N}_{1} \mathrm{~B}^{\mathrm{ii}}$ & $2.001(5)$ & $\mathrm{Cu} B \mathrm{~B}-\mathrm{N}_{1} \mathrm{~B}^{\mathrm{ii}}$ & $2.003(4)$ \\
\hline $\mathrm{Cu}_{1} \mathrm{~B}-\mathrm{N}_{4} \mathrm{~B}$ & $2.021(5)$ & 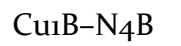 & $2.002(4)$ \\
\hline $\mathrm{Cu} B \mathrm{~B}-\mathrm{N}_{4} \mathrm{~B}^{\mathrm{ii}}$ & $2.021(5)$ & $\mathrm{Cu} B-\mathrm{N}_{4} \mathrm{~B}^{\mathrm{ii}}$ & $2.002(4)$ \\
\hline $\mathrm{Cu} B-\mathrm{O}_{5}$ & $2.526(3)$ & $\mathrm{Cu} B \mathrm{~B}-\mathrm{O}_{5}$ & $2.533(3)$ \\
\hline $\mathrm{Cu} B-\mathrm{O}_{5}{ }^{\mathrm{ii}}$ & $2.525(3)$ & $\mathrm{Cu} B-\mathrm{O}_{5}{ }^{\mathrm{ii}}$ & $2.533(3)$ \\
\hline $\mathrm{Cu} C-\mathrm{N} 1 \mathrm{C}$ & $2.020(5)$ & $\mathrm{CulC}-\mathrm{NiC}$ & $2.003(4)$ \\
\hline $\mathrm{CulC}-\mathrm{N}_{1} \mathrm{C}^{\mathrm{iii}}$ & $2.020(5)$ & $\mathrm{CulC}-\mathrm{N}_{1} C^{\mathrm{iii}}$ & $2.003(4)$ \\
\hline $\mathrm{Cu} C-\mathrm{N}_{4} \mathrm{C}$ & $1.997(5)$ & $\mathrm{Cu} C-\mathrm{N}_{4} \mathrm{C}$ & $2.005(4)$ \\
\hline $\mathrm{Cu} C-\mathrm{N}_{4} \mathrm{C}^{\mathrm{iii}}$ & $1.997(5)$ & $\mathrm{Cu} C-\mathrm{N}_{4} \mathrm{C}^{\mathrm{iii}}$ & $2.005(4)$ \\
\hline $\mathrm{Cu} C-\mathrm{O}_{1}$ & $2.604(3)$ & $\mathrm{CulC}-\mathrm{O}_{1}$ & $2.571(3)$ \\
\hline $\mathrm{Cu} C-\mathrm{Oi}^{\mathrm{iii}}$ & $2.604(3)$ & $\mathrm{CurC}-\mathrm{O}{ }^{\mathrm{iii}}$ & $2.571(3)$ \\
\hline
\end{tabular}

Symmetry codes: i) $1-x, 1-y,-z$; ii) $2-x, 1-y, 1-z$; iii) $2-x,-y,-z$.

There are two types of $\{\mathrm{Cu}$ (cyclam) $\}$ units: the complexes $\mathrm{CurB}$ and $\mathrm{CurC}$ both play the role of linking moieties, whereas Cu1A is a charge balancing subunit. Selected bond lengths are given in Table 2. The coordination spheres of the $\mathrm{CuiB}$ and $\mathrm{CurC}$ centers show elongated octahedral $\mathrm{CuN}_{4} \mathrm{O}_{2}$ geometries with the four $\mathrm{N}$ atoms of the cyclam ligand forming the equatorial plane and the axial positions occupied by terminal $\mathrm{O}$ atoms from $\left(\mathrm{V}_{10} \mathrm{O}_{28}\right)^{6-}$ clusters. In contrast, the Cu1A moiety constitutes a square-planar 
complex (Figure $S_{7}$ in Supporting Information). According to the literature, transition metal complexes of the cyclam ligand can adopt up to 5 different geometrical isomers depending on the ligand conformation, and more specifically, on whether the $\mathrm{N}-\mathrm{H}$ bonds are located above or below the $\mathrm{MN}_{4}$ plane. ${ }^{22}$ Both $\mathrm{CuIB}$ and CuiC display the so-called trans-III configuration in which two $\mathrm{N}-\mathrm{H}$ bonds point to one side of the $\mathrm{CuN}_{4}$ equatorial plane and the other two N$\mathrm{H}$ bonds point to the opposite side. This is in good agreement with the results reported previously, which have shown that the most favorable configuration of a $\{\mathrm{Cu}($ cyclam $)\}$ complex with octahedral geometry is indeed the trans-III. ${ }^{33}$ In regard to square planar complexes, these studies have also demonstrated that the trans-I configuration gains stability over the trans-III when the coordination number of the metal center is reduced. In our case, however, the configuration of the CurA moiety remains the same as that of $\mathrm{CulB}$ and $\mathrm{CurC}$ in spite of showing squareplanar geometry.

The crystal packing of $\mathbf{1}$ consists in a supramolecular assembly of covalent hybrid layers in which the decavanadate anions are linked by the $\mathrm{CulB}$ and $\mathrm{CurC}$ bridging moieties along the [oo1] and [o10] directions, respectively (Figure 4). Thus, each decavanadate anion results connected to four neighboring clusters through four complexes whose grafting sites are $\mathrm{VO}_{6}$ octahedra belonging to either the central $\left\{\mathrm{V}_{6}\right\}$ rectangular core $(\mathrm{Cu1B})$ or to the dimeric caps (Cu1C). This arrangement leads to the formation of hybrid grids with water-accessible square-like voids in the $y z$ plane. A closely related bi-dimensional lattice with similar connectivity between building blocks has been reported for the $(\mathrm{Hpz})_{2}\left[\left\{\mathrm{Cu}(\mathrm{pz})_{4}\right\}_{2}\left(\mathrm{~V}_{10} \mathrm{O}_{28}\right)\right] \cdot 2 \mathrm{H}_{2} \mathrm{O}$ (pz $=$ pyrazole $),{ }^{18 a}$ although with the voids filled with Hpz cations in contrast to $\mathbf{1}$ (Figure S8 in the Supporting Information). For the second bi-dimensional hybrid decavanadate known, namely $\left[\left\{\mathrm{Ag}_{3}(\mathrm{dmso})_{6}\right\}\left\{\left(\mathrm{Ag}(\mathrm{dmso})_{2}\right\}\left(\mathrm{H}_{2} \mathrm{~V}_{10} \mathrm{O}_{28}\right)\right] \cdot 2 \mathrm{dmso}{ }^{18 \mathrm{~b}}\right.$ the grafting sites for the metalorganic linkers are bridging $\mathrm{O}$ atoms of the $\left\{\mathrm{V}_{6}\right\}$ core and the presence of linear trimeric $\left[\mathrm{Ag}_{3}(\mathrm{dmso})_{6}\right]^{3+}$ moieties renders a rectangular hybrid grid. In both cases, the voids are inaccessible because they are blocked on both sides by clusters from adjacent layers.

In our case, the stacking of hybrid grids along the [100] direction is such that the square-like voids result superimposed on each other and this type of supramolecular assembly generates channels parallel to the crystallographic $x$ axis in which all of the water molecules are hosted (Figure 4a). Thus, the walls of these channels are delimited by rings of four $\left(\mathrm{V}_{10} \mathrm{O}_{28}\right)^{6-a n i o n s}$ and four $\{\mathrm{Cu}(\text { cyclam })\}^{2+}$ complexes in alternate fashion with approximate cross-section of 10.4 $\times 8.8 \AA^{2}$ (distances $\mathrm{N}_{4} \mathrm{C} \cdots \mathrm{N}_{4} \mathrm{C}$ and $\mathrm{N}_{1} \mathrm{~B} \cdots \mathrm{N}_{1} \mathrm{~B}$, Figure $4 \mathrm{~b}$ ). The total solvent accessible volume is $428 \AA^{3}$, which corresponds to approximately $25 \%$ of the unit cell volume as calculated using PLATON. ${ }^{23}$ The surface representation of the channel volume and that of the porous hybrid framework is given in Figure $4 c$.
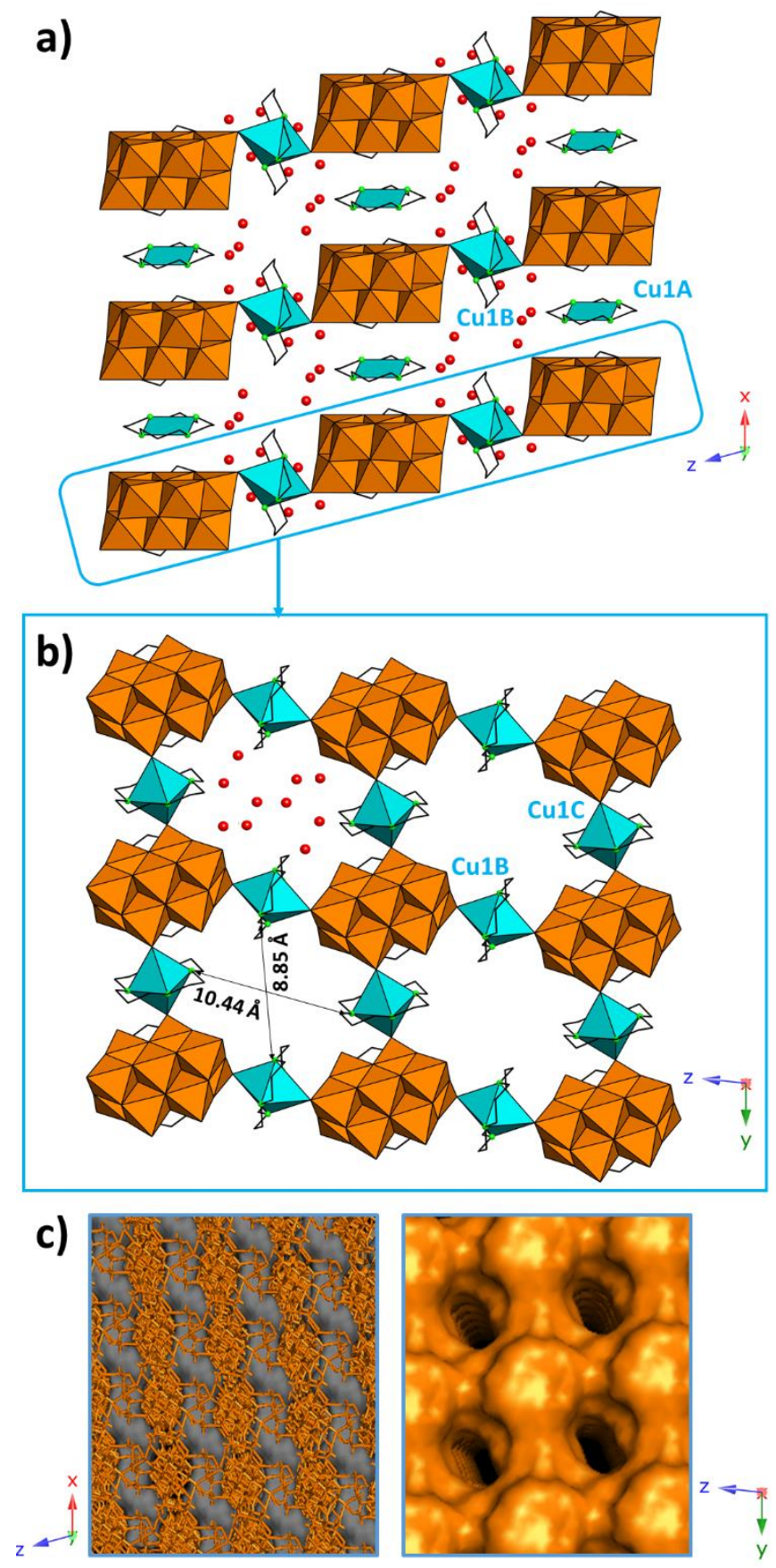

Figure 4. a) Crystal packing of 1 viewed along the crystallographic $y$ axis; b) Crystal packing of $\mathbf{1}$ viewed along the crystallographic $x$ axis, with details of the hosted water molecules and the estimated dimensions of the channels; c) Surface representations of the channels running along the crystallographic $x$ axis (left) and the surface of the porous network; color code: $\left\{\mathrm{VO}_{6}\right\}$ (orange octahedra), $\mathrm{Cu}$ (blue polyhedra), $\mathrm{N}$ (green), O (red); hydrogen atoms are omitted for clarity. 


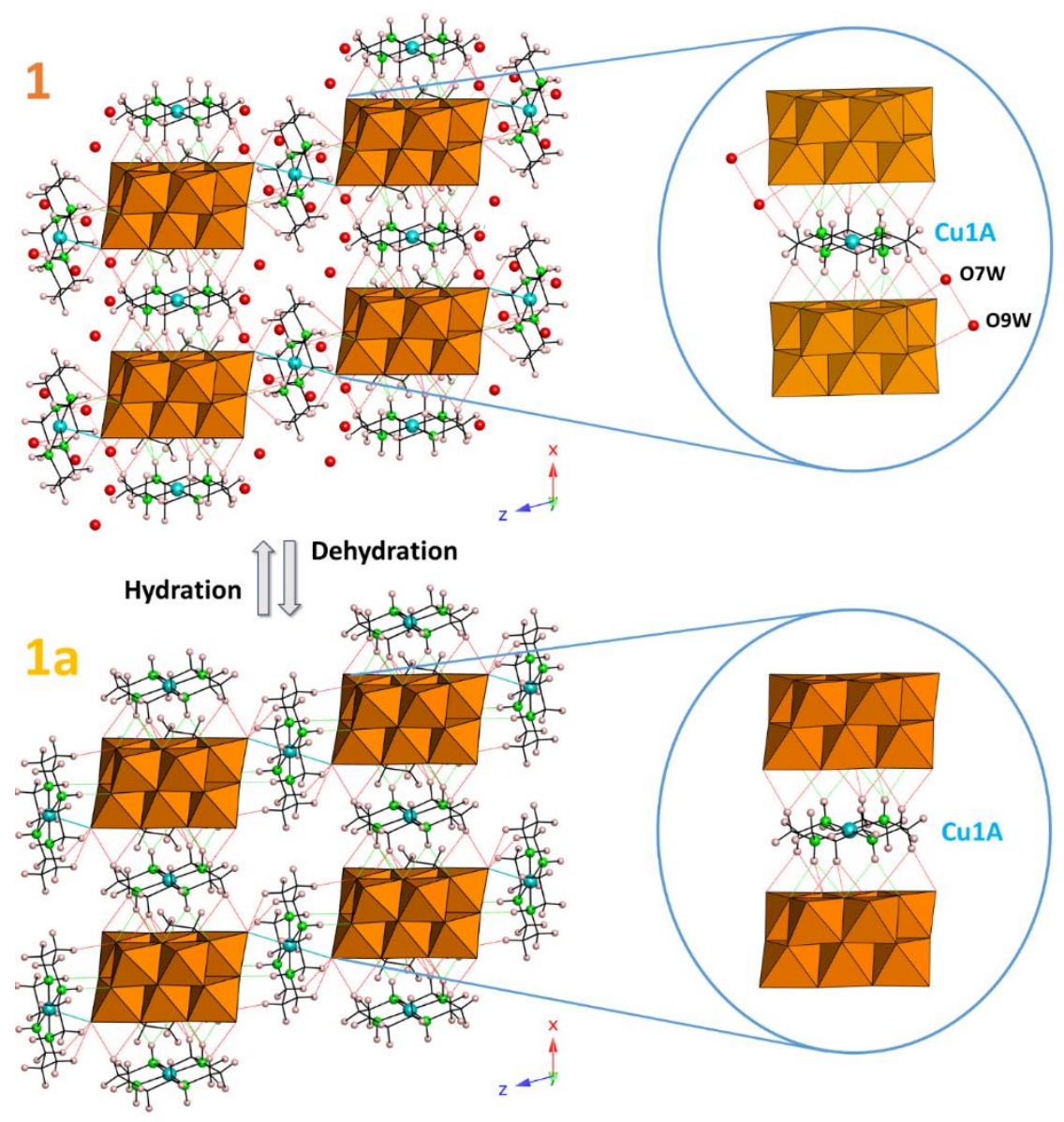

Figure 5. Comparison of the extensive network of $\mathrm{C}-\mathrm{H} \cdots \mathrm{O}$ (red) and $\mathrm{N}-\mathrm{H}$... O (green) interactions in $\mathbf{1}$ (top) and 1a (bottom) with details of the $\mathrm{H}$-bond network along the $x$ axis. Color code: $\left\{\mathrm{VO}_{6}\right\}$ (orange), $\mathrm{Cu}$ (blue), $\mathrm{N}$ (green), $\mathrm{O}$ (red), $\mathrm{H}$ (pink).

The square-planar CuiA complex cation occupies interlamellar spaces and is sandwiched in between ditriangular faces of two $\left(\mathrm{V}_{10} \mathrm{O}_{28}\right)^{6-}$ clusters belonging to different layers (Figure 4a). Indeed, the $\mathrm{Cu1A}$ atom is located at a distance of 3.0730(2) Å from the plane formed by the bridging O atoms of these faces ( $\mathrm{O}_{12}, \mathrm{O}_{15}, \mathrm{O}_{24}$ and $\left.\mathrm{O}_{34}\right)$. Despite the absence of any coordination bond connecting the layers, an extensive network of $\mathrm{C}-\mathrm{H} \cdots \mathrm{O}$ and $\mathrm{N}-\mathrm{H}$... O interactions is established between the cyclam ligand of the CurA complex and the surfaces of the sandwiching clusters. It should be noted that these interactions are more numerous and more favorable than those established by $\mathrm{Cu} B$ and $\mathrm{Cu} C$ complexes within layers (Tables $\mathrm{S}_{2}$ in the Supporting Information). As a result, the CuiA cation acts as an effective cementing agent to reinforce the stacking of the covalent layered lattices into a supramolecular open-framework material. In comparison, the water molecules of hydration do not appear to have any relevant structural role because they are weakly bound and do not interact with neither the cyclam ligands nor the terminal oxygen atoms of the clusters. In fact, only $\mathrm{O}_{7} \mathrm{~W}$ and $\mathrm{O}_{9} \mathrm{~W}$ appear to slightly contribute to the massive $\mathrm{H}$-bond network amongst hybrid layers and $\mathrm{Cu} A \mathrm{~A}$ cementing complexes (Figure 5 ). It is worth mentioning that another decavanadate-containing hybrid compound sharing similar metalorganic building blocks can be found in the literature, namely
$\left[(\mathrm{CuL})_{0.5}\left(\mathrm{H}_{2} \mathrm{~L}\right)_{1.5}\right]\left[\mathrm{H}_{2} \mathrm{~V}_{10} \mathrm{O}_{28}\right] \cdot 6 \mathrm{H}_{2} \mathrm{O} .{ }^{17 a}$ In this case, the macrocyclic polyamine ligand $(\mathrm{L})$ is the hexamethyl derivative of cyclam $(5,5,7,12,12,14$-hexamethyl-1,4,8,11-tetraazacyclotetradecane) and the inorganic cluster is diprotonated. The structure contains hybrid chains of alternating clusters and complexes, which arrange in supramolecular sheets via hydrogen bonding as opposed to the covalent bi-dimensional lattice of compound $\mathbf{1}$.

Guest solvent molecules located in cavities or channels can often be removed from a given host material without causing the crystalline collapse of the porous framework. This should be the case for $\mathbf{1}$ according to the variable-temperature PXRD results. To determine whether the supramolecular three-dimensional assembly of $\mathbf{1}$ is robust enough to effectively maintain its open framework nature upon dehydration and to identify any structural change triggered by the release of the guest solvent, we attempted to perform single-crystal XRD experiments on crystals of $\mathbf{1}$ heated to $130{ }^{\circ} \mathrm{C}$ to evacuate all hydration water in the channels. Fortunately, the crystals maintained their integrity upon thermal treatment, and hence, full data collection on the ra anhydrous form could be carried out. As expected from the PXRD analyses, the structure of the anhydrous phase proved to be virtually identical to that of the hydrated 1. Both the cell parameters and the relative arrangement of building blocks in the asymmetric unit, as 
well as the bond lengths within and among the blocks, remained almost invariable as shown in Tables 1 and 2, as well as in Figures S9-S11 in the Supporting Information. Moreover, the dimensions of the channels did neither undergo significant variations when $\mathbf{1}$ was dehydrated into $\mathbf{1 a}$ (Figure $\mathrm{S}_{22}$ in the Supporting Information), but for a subtle decrease of ca. $30 \AA^{3}$ in the total solvent accessible void according to PLATON calculations ( $397 \AA^{3}, 24 \%$ of the unit cell)

This absence of significant modifications in the metal atom positions of the constituent building blocks upon evacuation of guest solvent molecules confirms the robustness of the open hybrid framework, as well as the fact that the water molecules (including $\mathrm{O}_{7} \mathrm{~W}$ and $\mathrm{O}_{9} \mathrm{~W}$ ) do not fulfill any key structural role. This fact is consistent with the few intermolecular interactions observed between lattice water molecules and the decavanadate clusters or the cyclam ligands for the hydrated compound 1. Nevertheless, some subtle changes in the extensive hydrogen-bonding network can be observed when transforming $\mathbf{1}$ into $\mathbf{1 a}$. The thermally triggered dehydration produces a rotation of the metal-organic complexes around their axial axes that slightly modifies some of the intermolecular $\mathrm{C}-\mathrm{H} \ldots \mathrm{O}$ and $\mathrm{N}-\mathrm{H} \cdots \mathrm{O}$ interactions between the cyclam ligands and the cluster surfaces (Figure 5 and Table S2 in the Supporting Information). This relative rotation is notably more accused for the $\mathrm{CulB}$ moiety (approximately $20^{\circ}$ ) than for the $\mathrm{Cu} A \mathrm{~A}$ and $\mathrm{CurC}$ complexes (less than $10^{\circ}$ ), but the overall number of favorable interactions is maintained nearly constant. Moreover, the interlamellar distance correlated with that of the Cu1A center to the plane formed by the O12, O15, $\mathrm{O}_{24}$ and $\mathrm{O}_{34}$ atoms remains virtually identical (3.0889(1) $\AA$, Figure S9 in the Supporting Information), showing that our hybrid open-framework does not undergo any compression upon dehydration, and hence proving its robustness and permanent microporous nature.

\section{Sorption Properties}

The separation of small gases such $\mathrm{N}_{2}$ and $\mathrm{CO}_{2}$ is an important topic from industrial and environmental viewpoints. Since the channel dimensions found in the openframework of 1 are larger than those of $\mathrm{N}_{2}$ and $\mathrm{CO}_{2}$, we decided to explore whether 1 could exhibit gas sorption properties. Our studies revealed that $\mathbf{1}$ does not exhibit the capability to adsorb $\mathrm{N}_{2}$ while $\mathrm{CO}_{2}$ adsorption does take place (Figure 6). This fact can be explained taking into account the presence of narrow microporosity in 1. Although the kinetic diameter of the $\mathrm{CO}_{2}$ and $\mathrm{N}_{2}$ molecules (3.3 $\AA$ vs. 3.6 $\AA$ ) are similar, the higher adsorption temperature for $\mathrm{CO}_{2}$ confers the gas molecules a larger kinetic energy that favors their access into the narrow porosity, whereas $\mathrm{N}_{2}$ molecules are kinetically restricted due to the low temperatures at which the adsorption of this gas is performed. ${ }^{26,34}$

Compound $\mathbf{1}$ displays a type I isotherm for $\mathrm{CO}_{2}$ adsorption, which is indeed characteristic of a microporous material (Figure 6). In regard to the characterization of its porous texture, it is first worth noticing that while the total micropore volume obtained from the $\mathrm{N}_{2}$ adsorption corresponds to the whole range of microporosity (pore size up to $2 \mathrm{~nm}$ ), the $\mathrm{CO}_{2}$ adsorption $\left(\mathrm{V}_{\mathrm{CO}_{2}}\right)$ only provides specific information about narrow microporosity only (pore size < $0.8 \mathrm{~nm}$ ). The volume of the micropores in $\mathbf{1}$ is $0.11 \mathrm{~cm}^{3} \mathrm{~g}^{-1}$, while the BET (Brunauer-Emmett-Teller) surface area is $205 \mathrm{~m}^{2} \mathrm{~g}^{-1}$, as calculated from the $\mathrm{CO}_{2}$ sorption isotherm at $273 \mathrm{~K}$. These experimental data confirm that the micropores with approximate cross-sections of $10.4 \times 8.8 \AA^{2}$ observed from single-crystal XRD studies (Figure $4 \mathrm{~b}$ ) are accessible and fully operative, which endows the hybrid open-framework of $\mathbf{1}$ with functionality in $\mathrm{CO}_{2}$ capturing.

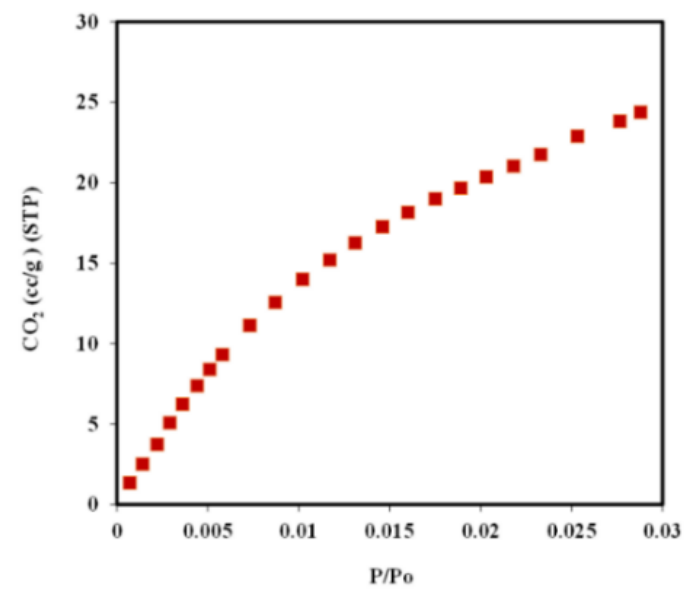

Figure 6. Type I isotherm of $\mathrm{CO}_{2}$ adsorption at $\mathrm{o}{ }^{\circ} \mathrm{C}$ for $\mathbf{1}$.

Reports on BET data for POM-based crystalline openframework materials are scarce. ${ }^{\mathrm{b}} \mathrm{A}$ limited number of microporous hybrid compounds with $\mathrm{CO}_{2}$ adsorption capability can be found in the literature. Mizuno's $\mathrm{K}_{2}\left[\mathrm{Cr}_{3} \mathrm{O}(\mathrm{OOCH})_{6}(4 \text {-ethylpyridine })_{3}\right]_{2}\left[\alpha-\mathrm{SiW}_{12} \mathrm{O}_{40}\right]$ is a representative example as it shows a high $\mathrm{CO}_{2} / \mathrm{C}_{2} \mathrm{H}_{2}$ sorption selectivity. ${ }^{5}$ The closely related $\left[\mathrm{Cr}_{3} \mathrm{O}\left(\mathrm{OOCCH}=\mathrm{CH}_{2}\right)_{6}\left(\mathrm{H}_{2} \mathrm{O}\right)_{3}\right]_{3}\left[\alpha-\mathrm{PW}_{12} \mathrm{O}_{40}\right]$ ionic crystal displays shape-selective adsorption of $\mathrm{CO}_{2}$ and $\mathrm{C}_{2} \mathrm{H}_{2}$ over the larger $\mathrm{N}_{2}$ and methane molecules, due to the kinetic diameters of the former being comparable to the minimum pore aperture. $5^{\mathrm{d}}$ Compared to our compound, both examples show lower BET surface areas ( 75 and $50 \mathrm{~m}^{2} \mathrm{~g}^{-1}$, respectively) and this can be explained attending to their smaller channel apertures ( $3.5 \AA$ and $3.3 \AA$, respectively). Some fully inorganic POM-based microporous materials have also displayed $\mathrm{CO}_{2}$ sorption properties. For example, Ueda et al reported two inorganic microporous materials based on $\varepsilon$-Keggin-type clusters, ${ }^{8 b, d}$ but both the BET surface areas and micropore volumes are approximately three to four times lower than those estimated for our compound. Wang et al. recently prepared the $(\mathrm{TBA})_{2}\left[\mathrm{Cu}{ }^{\mathrm{II}}(\mathrm{BBTZ})_{2}(\alpha-\right.$ $\left.\mathrm{Mo}_{8} \mathrm{O}_{26}\right)$ ] POMOF (BBTZ = 1,4-bis(1,2,4-triazol-1-ylmethyl)-benzene), which exhibits the highest adsorption capacity reported for a POM-based hybrid. ${ }^{10 a}$ The $\mathrm{CO}_{2}$ uptake capacity at saturation of $165 \mathrm{~cm}^{3} \mathrm{~g}^{-1}$ at $195 \mathrm{~K}$ and $87.7 \mathrm{~cm}^{3} \mathrm{~g}$ ${ }^{1}$ at $273 \mathrm{~K}$ is comparable to the best performing zeolite-like MOFs. ${ }^{2 a}$. These results together with a remarkable BET surface area of $773 \mathrm{~m}^{2} \mathrm{~g}^{-1}$ derive from the presence of a three-directional system of intersecting channels, as opposed to the system of parallel channels found in 1. In fact, 
the total solvent accessible volume is approximately 50\% of the unit cell volume which is roughly twice the empty volume observed for our compound $\mathbf{1}$ upon thermal activation. To our knowledge, compound $\mathbf{1}$ is the first decavanadate-based crystalline material that exhibits $\mathrm{CO}_{2}$ sorption capability as a straightforward consequence of i) the robust nature of its supramolecular open-framework structure and ii) the appropiate dimensions and accessibility of the channels.

\section{Catalytic activity tests}

The POM-catalyzed oxidation of hydrocarbons has been thoroughly studied over the past decades owing to its importance from industrial and synthetic viewpoints. 35 In this context, much attention has been paid to the oxidation of the tricyclic saturated hydrocarbon adamantane because this particular reaction is used as a probe to measure the $\mathrm{C}-\mathrm{H}$ bond activation ability of a given catalyst. Thus, several compounds have been tested in both homogeneous and heterogeneous phase with different oxidizing agents (e.g. PhI, $\mathrm{NaOCl}, \mathrm{H}_{2} \mathrm{O}_{2}, \mathrm{O}_{2}$, alkyl hydroperoxides, percarboxylic acids), affording a great variety of results in terms of conversion and selectivity. ${ }^{36}$

Table 3. Conversion of Adamantane and Selectivity after 6 Hours of Reaction in Different Cycles

\begin{tabular}{lccccccc}
\hline \multicolumn{1}{c}{ Catalyst } & Time & Conv. & \multicolumn{4}{c}{ aSelectivity (\%) } \\
& $(\mathbf{h})$ & $(\%$ mol $)$ & bP1 & $\mathbf{P 2}_{2}$ & $\mathbf{P}_{\mathbf{3}}$ & $\mathbf{P}$ \\
\hline None & 24 & 0 & - & - & - & - \\
$\mathrm{H}_{3}\left[\mathrm{PMo}_{12} \mathrm{O}_{40}\right]$ & 6 & 0 & - & - & - & - \\
$\mathrm{H}_{4}\left[\mathrm{PVMo}_{11} \mathrm{O}_{40}\right]$ & 6 & 90 & 45 & 30 & 11 & 13 \\
$\mathrm{Compound}_{1}$ & 3 & 38 & 45 & 26 & 28 & 1 \\
& 6 & 99 & 36 & 20 & 31 & 13 \\
$\mathrm{~V}_{2} \mathrm{O}_{5}$ & 6 & 50 & 22 & 23 & 8 & 47 \\
\hline
\end{tabular}

a based on the initial moles of adamantane; ${ }^{\mathrm{b}} \mathrm{P} 1$ : 1-Adamantanol (1AdOH), P2: 2-Adamantanone (2-AdO), P3: 2-Adamantanol (2-AdOH), P: Other products (1,3-Adamantanediol, 5-hydroxy-2-adamantanone, 1,3,5-Adamantanetriol). Experimental conditions: $75^{\circ} \mathrm{C}, 4 \cdot 10^{-5}$ moles of catalyst; $25 \mathrm{mg}$ adamantane; $3 \mathrm{~cm}^{3}$ of hydrogen peroxide $(30 \%) ; 10 \mathrm{~cm}^{3}$ of solvent (acetonitrile).

Scheme 1. $\mathrm{H}_{2} \mathrm{O}_{2}$-based Oxidation of Adamantane Using Compound 1 as Heterogeneous Catalyst

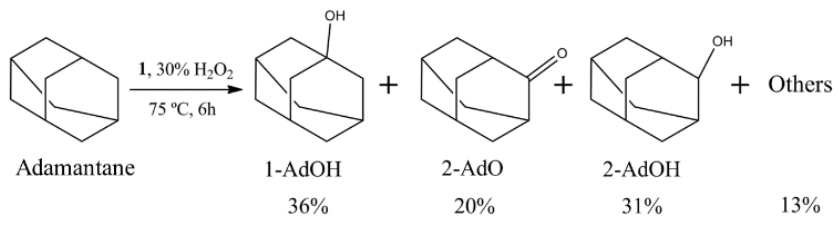

The catalytic activity of $\mathbf{1}$ toward the oxidation of adamantane has been explored in heterogeneous phase using hot acetonitrile as solvent and an environmentally friendly oxidant such as $\mathrm{H}_{2} \mathrm{O}_{2}$. Some other archetypal POM catalysts $\left(\mathrm{H}_{3}\left[\mathrm{PMo}_{12} \mathrm{O}_{40}\right]\right.$ and $\left.\mathrm{H}_{4}\left[\mathrm{PVMo}_{11} \mathrm{O}_{40}\right]\right)$, as well as $\mathrm{V}_{2} \mathrm{O}_{5}$, have also been tested in the same experimental conditions for comparative purposes (Table 3). As expected, the reaction does not take place in the absence of any catalyst under the selected experimental conditions due to the high stability of the tricyclic alkane. It is also remarkable that the $\mathrm{H}_{3}\left[\mathrm{PMo}_{12} \mathrm{O}_{40}\right]$ heteropolyacid, which is a well-established oxidation catalyst for a range of organic substrates, 35 is in fact inactive in our conditions. The replacement of molybdenum centers with vanadium atoms in the framework of Keggin-type anions has proven to be beneficial for redox catalysis as it enhances the redox character of the cluster. 37 The higher catalytic activity observed for the mono-substituted $\mathrm{H}_{4}\left[\mathrm{PVMo}_{11} \mathrm{O}_{40}\right]$ species in this reaction (90\% conversion after $6 \mathrm{~h}$ ) is in good agreement with the comment above. In comparison, the catalytic activity of $\mathrm{V}_{2} \mathrm{O}_{5}$ is lower than that of the vanadium-containing Keggin type heteropolyacid ( $50 \%$ conversion after $6 \mathrm{~h}$ ) despite the higher content of $\mathrm{V}$ atoms. These results are consistent with those reported by other authors, which suggests that vanadium constitutes the catalytic center for this reaction while the Keggin-type framework serves as scaffold to enhance its activity. ${ }^{38}$

Compound 1 displays the highest activity among all catalysts tested in this study, reaching a conversion of $99 \%$ after just 6 hours of reaction. The distribution of the reaction products shows low-to-moderate selectivity toward 1Adamantanol (1-AdOH) over other products from oxidation at secondary $\mathrm{C}-\mathrm{H}$ bonds (2-AdOH, 2-Adamantanone). Selectivity toward $1-\mathrm{AdOH}$ reaches a maximum of $45 \%$ after $3 \mathrm{~h}$ of reaction and decreases to $36 \%$ after $6 \mathrm{~h}$ due to the formation of other overoxidized side-products (Table 3 and Scheme 1). To our knowledge, no reports on the catalytic activity of decavanadate-containing compounds toward the $\mathrm{H}_{2} \mathrm{O}_{2}$-based oxidation of cycloalkanes can be found in the literature.

The fact that compound $\mathbf{1}$ affords the highest conversion in the shorter reaction time among all selected catalysts is worth remarking because vanadium substituted Keggintype species like the $\mathrm{H}_{4}\left[\mathrm{PVMo}_{11} \mathrm{O}_{4 \mathrm{o}}\right]$ comparative model have been identified as catalysts with the highest activity among POMs and certainly higher than those of transition-metal complexes such as $\mathrm{VO}(\text { acac })_{2} .{ }^{35}$ As an illustrative comparison of the higher activity of 1,12 hours of reaction were needed to reach conversions in the $49-65 \%$ range when vanadium-substituted phosphomolybdate acids heterogenized in SBA15 mesoporous silica were used with butyronitrile as solvent. ${ }^{38 a}$ When turning to homogeneous phase, several other POMs have been found to catalyze the oxidation of adamantane with $\mathrm{H}_{2} \mathrm{O}_{2}$ in acetonitrile, such as the divanadium-substituted phosphotungstate [ $\gamma-$ $\left.\mathrm{PW}_{10} \mathrm{O}_{38} \mathrm{~V}_{2}(\mu-\mathrm{OH})(\mu-\mathrm{O})\right]^{4-}$, hybrid species consisting of a metallosalen moiety covalently linked to a Keggin-type silicotungstate $\left[\mathrm{SiW}_{11} \mathrm{O}_{39}\right]^{8-}$, or the $\left[\gamma-\mathrm{SiW}_{10}\left\{\mathrm{Fe}\left(\mathrm{OH}_{2}\right)\right\}_{2} \mathrm{O}_{38}\right]^{6-}$ cluster. ${ }^{39}$ These species yield conversions from 42 up to $98 \%$, but the selectivity is much improved to values in the 74-94\% range toward 1-AdOH except for the iron-containing catalyst, which affords a selectivity of $71 \%$ toward the $2-\mathrm{AdOH}$ derivative. ${ }^{39 \mathrm{~d}}$

The high catalytic activity displayed by 1 could originate from its larger atomic proportion of vanadium per mole of 
catalyst. However, the tested $\mathrm{V}_{2} \mathrm{O}_{5}$ does show a significantly lower conversion, and hence other effects must also be influencing the catalytic performance of $\mathbf{1}$. The $\{\mathrm{Cu}($ cyclam $)\}$ metalorganic moieties coordinated to the $\left\{\mathrm{V}_{10} \mathrm{O}_{28}\right\}$ clusters could very well be responsible for enhancing the catalytic activity of the $\mathrm{V}$ centers, in close analogy with the role of the Keggin scaffold in the vanadium-substituted phosphomolybdates. Moreover, the permanent porosity of the hybrid open-framework, as well as the dimensions of the channels in $\mathbf{1}$, may also have a key enhancing effect.

\section{CONCLUSIONS}

The first POMOF-like hybrid compound with supramolecular microporous open-framework based on decavanadate clusters, namely $[\mathrm{Cu}($ cyclam $)]\left[\{\mathrm{Cu}(\text { cyclam })\}_{2}\left(\mathrm{~V}_{10} \mathrm{O}_{28}\right)\right] \cdot 10 \mathrm{H}_{2} \mathrm{O}(\mathbf{1})$, has been synthetized and fully characterized. The supramolecular architecture contains covalent decavanadate $/\{\mathrm{Cu}($ cyclam $)\}$ grids with square-like voids the stacking of which is driven by a massive network of intermolecular $\mathrm{N}-\mathrm{H} \cdots \mathrm{O}$ and $\mathrm{C}-$ $\mathrm{H}$... O interactions established with interlamellar cementing complexes. The structure is able to remain virtually unaltered upon thermal evacuation of guest solvent molecules located in the system of parallel channels generated by the stacking of the hybrid layers, as evidenced by a single crystal X-ray diffraction studies on the anhydrous 1a derivative. The permanent microporous nature of $\mathbf{1}$ results in functional properties such as selective adsorption of $\mathrm{CO}_{2}$ gas over $\mathrm{N}_{2}$ and remarkable catalytic activity toward the oxidation of the highly-stable organic substrate adamantane in heterogeneous phase. To our knowledge, this is the first decavanadate-based hybrid compound that shows both $\mathrm{CO}_{2}$ sorption capability and catalytic activity in the oxidation of cycloalkanes owing to its microporous nature, accessibility of channels and robustness of the framework.

\section{ASSOCIATED CONTENT}

\section{Supporting Information}

FT-IR spectra, PXRD patterns, structural figures and tables, and X-ray crystallographic data for $\mathbf{1}$ and $\mathbf{1 a}$ in CIF format (CCDC 1426650, 1426651). The Supporting Information is available free of charge via the Internet at http://pubs.acs.org.

\section{AUTHOR INFORMATION}

\section{Corresponding Author}

*E-mail: juanma.zorrilla@ehu.es

*E-mail: joseluis.vilas@ehu.es

\section{Notes}

The authors declare no competing financial interests.

\section{ACKNOWLEDGMENTS}

This work was funded by Eusko Jaurlaritza/Gobierno Vasco (grant IT477-10), MINECO (grant MAT2013-48366-C2-2-P), and UPV/EHU (grant UFI1/53). J. A.-M. thanks Generalitat Valenciana and FEDER (grant PROMETEO2/2014/o10), as well as MINECO (grant CTQ2015-64801) for financial support.
Technical and human support provided by SGIker (UPV/EHU) is gratefully acknowledged.

\section{REFERENCES}

(1) (a) Furukawa, H.; Cordova, K. E.; O’Keeffe, M.; Yaghi, O. M. Science 2013, 341, 974-986. (b) Guest. Eds. Zhou, H.-C.; Long, J. R.; Yaghi, O. M. Chem. Rev. 2012, 112, thematic issue 2. (c) Liu, J.; Thallapally, P. K.; McGrail B. P.; Brown, D. R.; Liu, J. Chem. Soc. Rev. 2012, 41, 2308-2322. (d) Long. J. R.; Yaghi, O. M. Chem. Soc. Rev. 2009, 38 , thematic issue 5 .

(2) See for example: (a) Qin, J.-S.; Du, D.-Y.; Li, W.-L.; Zhang, J.-P.; Li, S.-L.; Su, Z.-M.; Wang, X.-L.; Xu, Q.; Shao, K.-Z.; Lan, Y.Q. Chem. Sci. 2012, 3, 2114-2118. (b) Horcajada, P.; Chalati, T.; Serre, C.; Gillet, B.; Sebrie, C.; Baati, T.; Eubank, J. F.; Heurtaux, D.; Clayette, P.; Kreuz, C.; Chang, J.-S.; Hwang, Y. K.; Marsaud, V.; Bories, P.-N.; Cynober, L.; Gil, S.; Férey, G.; Couvreur P.; Gref, R. Nat. Mater. 2010, 9, 172-178. (c) Eddaoudi, M.; Kim, J.; Rosi, N.; Vodak, D.; Wachter, J.; O'Keeffe, M.; Yaghi, O. M. Science 2002, 295, 469-472. (c) Chen, B.; Zhao, X.; Putkham, A.; Hong, K.; Lobkovsky, E. B.; Hurtado, E. J.; Fletcher A. J.; Thomas, K. M. J. Am. Chem. Soc. 2008, 130, 6411-6423.

(3) (a) Miras, H. N.; Vilà-Nadal, L.; Cronin, L. Chem. Soc. Rev. 2014, 43, 5679-5699. (b) Du, D.-Y.; Qin, J.-S.; Li, S.-L.; Su, Z.-M.; Lan, Y.-Q. Chem. Soc. Rev. 2o14, 43, 4615-4632.

(4) (a) Pope, M. T. Heteropoly and Isopoly Oxometalates; Springer: Berlin, 1983. (b) Polyoxometalates: From Platonic Solids to Anti-Retroviral Activity; Pope, M. T., Müller, A., Eds.; Kluwer: Dordrecht, The Netherlands, 1994. (c) Polyoxometalate Chemistry: from Topology via Self-Assembly to Applications; Pope, M. T., Müller, A., Eds.; Kluwer: Dordrecht, The Netherlands, 20o1. (d) Guest Eds. Cronin, L.; Long, D.-L. Dalton Trans. 2o12, 41, thematic issue 33. (e) Guest Eds. Cronin, L.; Müller, A. Chem. Soc. Rev. 2012, 41 , thematic issue 24 .

(5) (a) Uchida, S.; Mizuno, N. Coord. Chem. Rev. 2007, 251, 2537-2546 and references therein. (b) Eguchi, R.; Uchida, S.; Mizuno, N. J. Phys. Chem. C 2012, 116, 16105-16110. (c) Eguchi, R.; Uchida, S.; Mizuno, N. Angew. Chem., Int. Ed. 2012, 51, 1635-1639. (d) Kawahara, R.; Uchida, S.; Mizuno, N. Inorg. Chem. 2014, 53, 3655-3661.

(6) Wang, Y.; Ye, L.; Wang, T.-G.; Cui, X.-B.; Shi, S.-Y.; Wang, G.-W.; Xu, J. Q. Dalton Trans. 2010, 39, 1916-1919.

(7) Han, J. W.; Hill, C. L. J. Am. Chem. Soc. 2007, 129, 15094-15095.

(8) (a) Liu, D.; Lu, Y.; Tan, H.-Q.; Chen, W.-L.; Zhang, Z.-M.; Li, Y.-G.; Wang, E.-B. Chem. Commun. 2o13, 49, 3673-3675. (b) Zhang, Z.; Sadakane, M.; Murayama, T.; Izumi, S.; Yasuda, N.; Sakaguchi, N.; Ueda, W. Inorg. Chem. 2o14, 53, 903-911. (c) An, H.; Hu, Y.; Wang, L.; Zhou, E.; Fei, F.; Su, Z. Cryst. Growth Des. 2015, 15, 164-175. (d) Zhang, Z.; Sadakane, M.; Noro, S.; Murayama, T.; Kamachi, T.; Yoshizawa, K.; Ueda, W. J. Mater. Chem. A, 2015, 3, 746-755.

(9) (a) Nohra, B.; El Moll, H.; Rodriguez Albelo, L. M.; Mialane, P.; Marrot, J.; Mellot-Draznieks, C.; O’Keeffe, M.; Biboum, R. N.; Lemaire, J.; Keita, B.; Nadjo, L.; Dolbecq, A. J. Am. Chem. Soc. 2o11, 133, 13363-13374. (b) Qin, J.-S.; Du, D.-Y.; Guan, W.; Bo, X.-J.; Li, Y.-F.; Guo, L.-P.; Su, Z.-M.; Wang, Y.-Y.; Lan, Y.-Q.; Zhou, H.-C. J. Am. Chem. Soc. 2015, 137, 7169-7177. (c) Zheng, S.-T.; Zhang, J.; Yang, G.-Y. Angew. Chem. Int. Ed. 2008, 47, 3909-3913.

(10) (a) Fu, H.; Qin, C.; Lu, Y.; Zhang, Z.-M.; Li, Y.-G.; Su, Z.-M.; Li, W.-L.; Wang, E.-B. Angew. Chem. Int. Ed. 2o12, 51, 7985-7989. (b) Wang, X.; Hu, H.; Liu, G.; Lin, H.; Tian, A. Chem. Commun. 2010, 46, 6485-6487. (c) An, H.-Y.; Wang, E.-B.; Xiao, D.-R.; Li, Y.G.; Su, Z.-M.; Xu, L. Angew. Chem. Int. Ed. 2006, 45, 904-908.

(11) Dolbecq, A.; Dumas, E.; Mayer, C. R.; Mialane, P. Chem. Rev. 2010, 110, 6009-6048.

(12) Hayashi, Y. Coord. Chem. Rev. 2011, 255, 2270-2280. 
(13) See for example: (a) Zhang, Y.; Zapf, P. J.; Meyer, L. M.; Haushalter, R. C.; Zubieta, J. Inorg. Chem. 1997, 36, 2159-2165. (b) Hayashi, Y.; Ozawa, Y.; Isobe, K. Inorg. Chem. 1991, 30, 1025-1033. (c) Chen, C.-L.; Goforth, A. M.; Smith, M. D.; Su, C.-Y.; zur Loye, H.-C. Angew. Chem., Int. Ed. 2005, 44, 6673-6677.

(14) See for example: (a) Iyer, A. K.; Roy, S.; Haridasan, R.; Sarkar, S.; Peter, S. C. Dalton Trans. 2014, 43, 2153-216o. (b) Schulz-Dobrick, M.; Jansen, M. Inorg. Chem. 20o7, 46, 438o-4382. (15) Li, T.; Lü, J.; Gao, S.; Li, F.; Cao, R. Chem. Lett. 2007, 36, 356-357.

(16) (a) McGlone, T.; Thiel, J.; Streb, C.; Long, D.-L.; Cronin, L. Chem. Commun. 2012, 48, 359-361. (b) Xu, W.; Jiang, F.; Zhou, Y.; Xiong, K.; Chen, L.; Yang, M.; Feng, R.; Hong, M. Dalton Trans. 2012, 41, 7737-7745.

(17) (a) Ou, G.-C.; Jiang, L.; Feng, X.-L.; Lu, T.-B. Dalton Trans. 2009, 71-76. (b) Kulikov, V.; Meyer, G. Cryst. Growth Des. 2013, 13 2916-2927.

(18) (a) Thomas, J.; Agarwal, M.; Ramanan, A.; Chernova, N.; Whittingham, M. S. CrystEngComm 2oo9, 11, 625-631. (b) Streb, C.; Tsunashima, R.; MacLaren, D. A.; McGlone, T.; Akutagawa, T.; Nakamura, T.; Scandurra, A.; Pignataro, B.; Gadegaard, N.; Cronin, L. Angew. Chem. Int. Ed. 2009, 48, 6490-6493.

(19) (a) Wéry, A. S. J.; Gutiérrez-Zorrilla, J. M.; Luque, A.; Ugalde, M.; Román, P. Chem. Mater. 1996, 8, 408-413. (b) Wéry, A. S. J.; Gutiérrez-Zorrilla, J. M.; Luque, A.; Román, P. Polyhedron 1996, 15, 4555-4564.

(20) CrysAlisPro Software System, Version 171.37.34; Agilent Technologies UK Ltd.: Oxford, U. K., 2012.

(21) Dolomanov, O. V.; Bourhis, L. J.; Gildea, R. J.; Howard, J. A.; Puschmann, H. J. J. Appl. Crystallogr. 2009, 42, 339-342.

(22) Sheldrick, G. M. Acta Crystallogr. 2008, A64, 112-122.

(23) Spek, A. L. Acta Crystallogr. 2009, D65, 148-155.

(24) Farrugia, L. J. J. Appl. Crystallogr. 1999, 32, 837-838.

(25) DeLano, W. L. The PyMOL Molecular Graphics System; DeLano Scientific: San Carlos, CA, 2002.

(26) (a) Polyakov, N. S.; Dubinin, M. M.; Kataeva, L. I.; Petuhova, G. A. Pure Appl. Chem. 1993, 65, 2189-2192. (b) CazorlaAmorós, D.; Alcañiz-Monge, J.; Linares-Solano, A. Langmuir 1996, 12, 2820-2824.

(27) Martín-Caballero, J.; Wéry, A. S. J.; Artetxe, B.; Reinoso, S.; San Felices, L.; Vilas, J. L.; Gutiérrez-Zorrilla, J. M. CrystEngComm 2015, 17, 8915-8925.
(28) Ketelaar, J. A. A. Chem. Weekbl. 1936, 33, 51-57.

(29) Mercurio-Lavaud, D.; Frit, B. C. R. Seances Acad. Sci., Ser.

C 1973, 277, 1101-1104.

(30) Brisi, C.; Molinari, A. Ann. Chim. Rome 1958, 48, 263-269.

(31) Román, P.; Aranzabe, A.; Luque, A; Gutiérrez-Zorrilla, J. M.; Martínez-Ripoll, M. J. Chem. Soc., Dalton Trans. 1995, 13, 22252231.

(32) Bosnich, B.; Poon, C. K.; Tobe, M. L. Inorg. Chem. 1965, 4, 1102-1108.

(33) Bakaj, M.; Zimmer, M. J. Mol. Struct. 1999, 508, 59-72.

(34) (a) Rodríguez-Reinoso, F.; Linares-Solano, A. Microporous Structure of Activated Carbons as Revealed by Adsorption Methods, Vol. 2; Dekker: New York, 1988. (b) Cazorla-Amorós, D.; Alcañiz-Monge, J.; de la Casa-Lillo, M. A.; Linares-Solano, A. Langmuir 1998, 14, 4589-4596.

(35) (a) Mizuno, N.; Kamata, K. Coor. Chem. Rev. 2011, 255, 2358-2370. (b) Kozhevnikov, I. V. Catalysts for Fine Chemical Synthesis, Vol 2; John Wiley \& Sons: Chichester, U. K., 2002. (c) Kozhevnikov, I. V. Catalysis by Polyoxometalates; John Wiley \& Sons: Chichester, U. K., 200o. (d) Mizuno, N.; Misono, M. Chem. Rev. 1998, 98, 199-218.

(36) See for example: (a) Joseph, T.; Hartmann, M.; Ernst, S.; Halligudi, S. B. J. Mol. Catal. A 2004, 207, 131-137. (b) Ishito, N.; Kobayashi, H.; Nakajima, K.; Maegawa, Y.; Inagaki, S.; Hara, K.; Fukuoka, A. Chem. Eur. J. 2015, 21, 15564-15569. (c) Bonchio, M.; Scorrano, G.; Toniolo, P.; Proust, A.; Artero, V.; Conte, V. Adv. Synth. Catal. 2002, 344, 841-844. (d) Farzaneh, F.; Moghzi, F. React. Kinet., Mech. Catal. 2015, 115, 175-185.

(37) Molinari, J. E.; Nakka, L.; Kim, T.; Wachs, I. E. ACS Catal. 2011, 1, 1536-1540.

(38) (a) Bordoloi, A.; Vinu, A.; Halligudi, S. B. Appl. Catal. A: Gen. 2007, 333, 143-152. (b) Shinachi, S.; Matsushita, M.; Yamaguchi, K.; Mizuno, N. J. Catal. 20o5, 233, 81-89.

(39) (a) Kamata, K.; Yonehara, K.; Nakagawa, Y.; Uehara, K.; Mizuno, N. Nat. Chem. 201o, 2, 478-483. (b) Mirkhani, V.; Moghadam, M.; Tangestaninejad, S.; Mohammadpoor-Baltork; I., Rasouli, N. Catal. Commun. 20o8, 9, 2171-2174. (c) Mizuno, N. Catal. Surv. Jpn 2ooo, 4, 149-154. (d) Mirkhani, V.; Moghadan, M.; Tangestaninejad, S.; Mohammadpoor-Baltork, I.; Rasouli, N. Catal. Commun. 2008, 9, 2411-2416. 


\section{SYNOPSIS TOC}

The supramolecular POMOF-like hybrid [Cu(cyclam)][\{Cu(cyclam) $\left.\}_{2}\left(\mathrm{~V}_{10} \mathrm{O}_{28}\right)\right] \cdot 10 \mathrm{H}_{2} \mathrm{O}(\mathbf{1})$ is constructed from the stacking of covalent decavanadate $/\{\mathrm{Cu}($ cyclam $)\}$ layers and robust enough to retain its open-framework nature upon thermal removal of all solvent molecules hosted in the channels. The permanent microporous nature of $\mathbf{1}$ provides interesting functionality such as selective adsorption of $\mathrm{CO}_{2}$ over $\mathrm{N}_{2}$ molecules and catalytic activity toward the $\mathrm{H}_{2} \mathrm{O}_{2}-$ based oxidation of the highly-stable hydrocarbon adamantane.

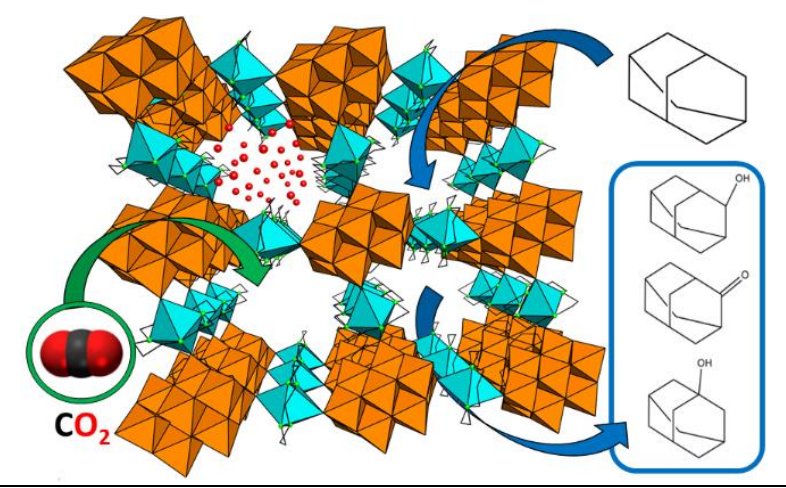

